\title{
The Effect of Company Size and Audit Opinion on Auditor Switching with Moderated by the Auditor's Reputation
}

\author{
Dhini Suryandari ${ }^{1}$, Fitriana Silva Dwiyanti ${ }^{2}$ \\ \{dhini.surya@mail.unnes.ac.id ${ }^{1}$, fitrianasilva99@gmail.com² ${ }^{2}$ \\ Universitas Negeri Semarang, Indonesia ${ }^{1,2}$
}

\begin{abstract}
This study aims to examine the effect of company size and audit opinion on auditor switching with KAP turnover indicators and add auditor's reputation as a moderating variable. Population of this research is 39 mining companies listed on the Indonesia Stock Exchange (IDX) in 2015-2018. The sample selection is done using a purposive sample method and produces 125 samples are processed. Data analysis method that used in this study are descriptive statistics analysis and inferential statistics analysis with absolute difference test for moderation with IBM SPSS 21 software. The results showed that company size has no effect on auditor switching, while audit opinion has a significant negative effect on auditor switching. The auditor's reputation strengthens the influence of company size on auditor switching, but the auditor's reputation is unable to strengthen the effect of audit opinion on auditor switching. The conclusion is a good opinion will minimize the practice of auditor switching and the large company supported by a good auditor reputation also can minimize the practice of auditor switching.
\end{abstract}

Keywords: Company Size, Audit Opinion, Auditor Reputation, Auditor Switching, KAP Switching

\section{Introduction}

Auditor switching is an action taken by a company or business entity to replace the auditor and the Public Accounting Firm (KAP) whom is given the task of conducting an audit of its financial statements. Auditor switching can be mandatory due to government regulations that govern or are voluntary based on the decisions of the company's management. Obligatory change of auditors in Indonesia is regulated in Government Regulation No. 20 of 2015 concerning the Practice of Public Accountants which no longer limits the Public Accounting Firm (KAP) to provide audit services on the financial statements of an entity, but Public Accountants (AP) are limited to conducting audit maximum of 5 years in a row. Even though KAP is no longer restricted, there are still many companies doing KAP changes. Whereas voluntary auditor turnover is usually based on dissatisfaction with the opinion given by the auditor on his financial statements.

The gap phenomenon in this study is the case of PT Garuda Indonesia Tbk (GIAA), who manipulated financial statements in 2019. It started with the results of the 2018 financial statements which posted a net profit of USD 809.85 thousand or around Rp 11.33 billion. That number jumped sharply compared to 2017 which suffered a loss of USD 216.5 million. Then it was discovered that the financial statements of GIAA were not presented in accordance with the 
Statement of Financial Accounting Standards (PSAK). The reason is, Garuda Indonesia includes profits from PT Mahata Aero Teknologi which has a debt to GIAA related to the installation of Wi-Fi that has not been paid. From this case, KAP Tanubrata Sutanto Fahmi Bambang \& Partners (BDO International Members) as an independent auditor of GIAA was found guilty because based on the results of the meeting with the KAP, it was concluded that the audit allegedly was not in accordance with accounting standards.

It is known that prior to using KAP Tanubrata Sutanto Fahmi Bambang \& Partners, from 2014-2017 PT Garuda Indonesia Tbk, was audited by KAP Satrio Bing Eny \& Partners affiliated with one of Deloitte's international big four auditors. Then after the case surfaced to the public, Garuda replaced its KAP with KAP Tanudiredja, Wibisana, Rintis \& Rekan in 2019 and was affiliated with one of PWC's international big four auditors. After entering into a four-year engagement with KAP Satrio Bing Eny \& Partners, Garuda decided to change the KAP in 2018 with KAP Tanubrata Sutanto Fahmi Bambang \& Partners who were non-big four KAPs. However, after the case was revealed, Garuda chose to use the big four KAP again. With the change of KAP from the big four KAP to non-big four KAP, it is feared that the fraud has been planned by management regarding the manipulation of its financial statements. Big four KAP is considered more capable of detecting fraud and with good credibility, the audit results on its financial statements are also considered to be of higher quality so that the opinions given are also more trusted. Therefore, in the year of fraud, Garuda chose a non-big four KAP with the hope that the fraud could not be detected. The change in KAP that is too frequent is also feared to be caused by company management trying to find auditors who can be invited to work together in manipulating financial statements.

This study seeks to examine the factors expected to have an influence in the practice of auditor changes made by a company. With the issuance of Government Regulation No. 20 of 2015 concerning the practice of public accountants which no longer limits KAP engagement with clients, it is expected that companies will not replace their KAPs too often to minimize fraud by the company's management.

The results of previous studies related to the factors used in this study still indicate inconsistencies, such as in researches Hartono \& Rohman [1], Gharibi \& Geraeely [2] and Saidin, Arifati \& Andini [3], which show the influence of company size on auditor switching, while researches Fakhri, Majidah \& Nurbaiti [4], Winata \& Anisykurlillah [5] and Fauziyyah, Sondakh \& Suwetja [6], state that company size has no effect on the occurrence of auditor changes in the company. In addition, the results inconsistency also occurs in the audit opinion variable, where the researches Fauziyyah, Sondakh \& Suwetja [6], Faradila \& Yahya [7] and Putra \& Suryanawa [8], indicate the influence of opinion audit of auditor switching, while researches Hartono \& Rohman [1], Winata \& Anisykurlillah [5] and Pawitri \& Yadnyana [9], show the results that audit opinion has no effect on the auditors' change .

Thus, researchers are interested in reviewing the effect of company size and audit opinion on auditor switching. The added value in this study is to augment the auditor's reputation variable as a moderating variable that is expected to strengthen or weaken the independent variable's influence on the dependent ones. In addition, this study uses objects of mining companies listed on the Indonesia Stock Exchange (IDX), which are still relatively rarely used in previous studies. 


\section{Literature Review and Hypotheses Development}

This study uses two basic theories namely agency theory and signal theory. Agency theory describes the relationship between shareholders acting as principals with management who act as agents. An agency relationship is a shareholder contract (principal) that carries out management's orders (agent) to perform a service on behalf of the principal and authorizes the agent to make the best decision for the principal. If both parties have the same goal to maximize the value of the company, then it is believed the agent will act in a manner that is in accordance with the principal's interests [10].

Management, which is an internal party of a company providing financial reports, tends to try to take action in the personal interests by abusing power. On the other hand, the shareholders want the financial statements to be presented properly so that it reflects the actual state of the company for retrieval. This has led to the emergence of agency costs, namely by presenting an independent third party and is considered capable of bridging these differences in interests and preventing the occurrence of information asymmetry, which is a situation where agents are superior in knowing and understanding information than other parties (principals and stakeholders).

The link between agency theory and company size is that large companies will have more business complexity. With that complexity, it can cause agency costs in the form of independent auditor services that are able to bridge the differences in interests between principals and agents. Agency theory is related to audit opinion, independent auditors as third parties are expected to be able to resolve conflicts between agents and principals by assessing the fairness of a company's financial statements by assigning an opinion on its audit.

Signal theory, developed by Spence [11], illustrates that companies with good performance will deliberately give signals to the market using financial information. The management will provide information related to the company's performance and prospects to investors. This information is considered as a signal to investors to be used as a reference in making investment decisions.

The relationship between signal theory and company size is that the greater the total sales, the greater the net profit so that dividends distributed to shareholders are also expected to be even greater. This is able to provide a positive signal to attract potential investors. The relationship between signal theory and audit opinion, that is, an unqualified audit opinion will give a good signal because the financial statements are considered to have been presented fairly and in accordance with established standards. The linkage of signal theory with the auditor's reputation is that auditors having a good reputation are believed to have good credibility and competence so that the audit results are quality and can be trusted more.

The size of the company can be assessed from total assets, total sales, market capitalization, number of workers and so on [12]. The large size of the company will have complex business activities requiring experienced KAPs who have an audit engagement with clients in the long run because they already know the business operations or industry specialization of the client so that the larger the size of the company, the less likely it is to replace the KAP [5].

\section{$\mathrm{H}_{1}$ : Company size has a negative effect on auditor switching.}

An audit opinion is a statement of opinion or auditor's opinion on a company's financial statements, after the auditor has examined the fairness of a company's financial statements [9]. According to the Professional Standards of Public Accountants as of March 31st, 2011 (PSA 29 
SA Section 508), there are five types of audit opinions, namely unqualified opinion, modified unqualified opinion, qualified opinion, adverse opinion, and disclaimer opinion. Management will be satisfied if the auditor gives a good opinion on the financial statements presented. Unqualified opinion is the opinion most desirable by management because it is believed to give a positive signal to potential investors. An audit opinion can be a cause for a client to change auditors when the client disagrees with the opinion given by the auditor in the previous year [13].

$\mathrm{H}_{2}$ : Audit opinion has a negative effect on auditor switching.

Large companies will tend to try to retain their auditors because they think that auditors already know the company's industry specialization so well that the audit will be conducted properly. Meanwhile, if changing auditors will take more time for new auditors to study the client's industry. This is reinforced if the auditor conducting an audit of the financial statements is an auditor who has a good reputation. The auditor's reputation is a big-name view held by the auditor for the achievements and public trust of the auditor and the Public Accounting Firm where the auditor works. Auditor's reputation is one proxy for assessing audit quality, therefore investors tend to entrust their money to be invested in companies that have accounting data generated by reputable auditors [14]. Auditors' reputation is proxy in KAP Big Four and NonBig Four. Large companies tend to have used KAP affiliated with The Big Four KAP. KAP affiliated with one of The Big 4 KAP is considered to have good credibility and competency so that they are able to learn the client's industry specialization well and will increase investor confidence in the audited financial statements.

Table 1. Big Four KAP Categories

\begin{tabular}{ll}
\hline KAP Indonesia & International Cooperation \\
\hline Tanudiredja, Wibisana, Rintis and Partners & Pricewaterhouse Coopers (PwC) \\
Satrio Bing Eny and Partners & Deloitte Touche Tohmatsu (Doloitte) \\
Purwantono, Sungkoro and Surja & Ernst dan Young Global (EY) \\
Siddharta Widjaja and Partners & Klynveld Peat Marwick Geordeler (KPMG) \\
\hline \multicolumn{2}{c}{ Source: pppk.kemenkeu, 2015. }
\end{tabular}

$\mathrm{H}_{3}$ : The auditor's reputation strengthens the effect of company size on auditor switching.

According to Juliantari \& Rasmini [15], clients who have received unqualified opinion tend not to replace their auditors, until the time limit set by the government because the opinion is in line with the expectations of the company's management. This will be further strengthened if the audit opinion is given by a reputable auditor. A reputable auditor is an auditor in the KAP affiliated with The Big Four KAP. In accordance with signal theory, that the auditor's opinion given by a reputable KAP will be more trusted by the public because it is considered to have high credibility and better audit quality on the financial statements compared to a small KAP so that the audit opinion given the company is deemed appropriate or reflects the real situation.

$\mathrm{H}_{4}$ : The auditor's reputation strengthens the effect of audit opinion on auditor switching 
Based on the theoretical framework, the research model can be illustrated in Figure 1.

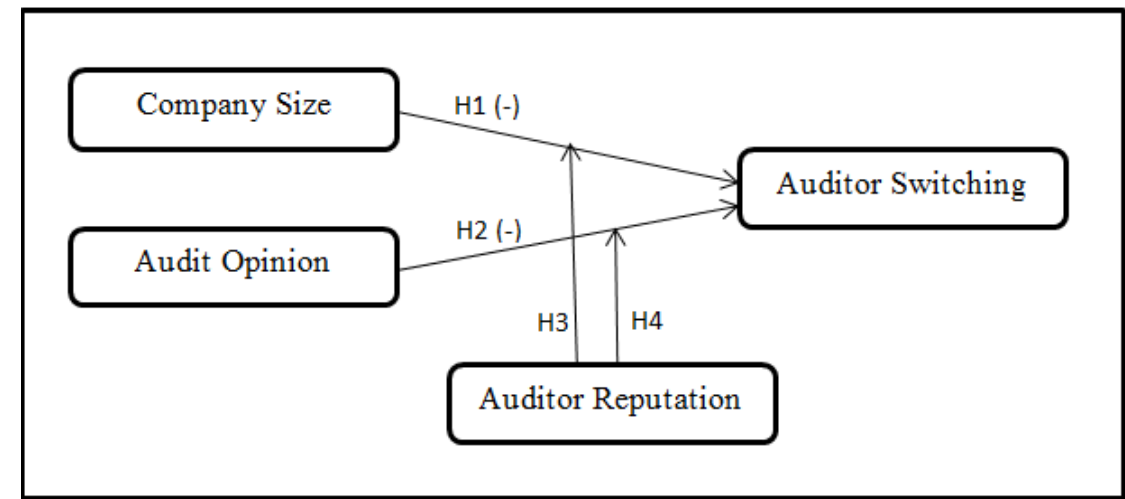

\section{Research Methods}

The research design used in this study is a hypothesis study. This research is a type of quantitative research. The data used in this study are secondary data obtained from audited financial statements of public companies in 2015-2018 which are listed on the Indonesia Stock Exchange (IDX) by accessing the official website of the Indonesia Stock Exchange (www.idx.co.id). Data collection method used in this study is the documentation method.

The population in this study are mining companies listed on the Stock Exchange and sample selection using purposive sampling technique and produced 125 sample that processed using SPSS 21 software.

Table 2. Sample Selection Process

\begin{tabular}{lc}
\hline \multicolumn{1}{c}{ Criteria } & Amount \\
\hline All mining companies registered in 2015-2018 on IDX & 39 \\
Companies that do not publish annual reports/do not publish audited financial & $(4)$ \\
statements for 2015-2018 & $(2)$ \\
Companies that do not have the required data for the period of 31th of & \\
December 2015-2018 & 33 \\
Number of sample companies & 4 \\
Observation Year & 132 \\
The Number of Observation Samples & $(7)$ \\
Outlier data & 125 \\
The final number of samples & \\
\hline
\end{tabular}
Source: Secondary Data Processed in 2020.

This study uses independent variables of company size and audit opinion. The auditor's reputation as a moderating variable and auditor switching as the dependent variable. 
Table 3. Operational Definitions and Measurement of Research Variables

\begin{tabular}{|c|c|c|}
\hline Variables & Definition & Measurement \\
\hline Auditor Switching (Y) & $\begin{array}{l}\text { Auditor switching is a change in the } \\
\text { Public Accounting Firm (KAP) or } \\
\text { auditor conducted by a client company } \\
{[16] \text {. }}\end{array}$ & $\begin{array}{l}\text { Switch KAP (1) Not } \\
\text { Switch KAP (0) }\end{array}$ \\
\hline Company Size (X1) & $\begin{array}{l}\text { The size of a company can be based on } \\
\text { total assets, sales, market } \\
\text { capitalization, number of workers and } \\
\text { others [12]. }\end{array}$ & $\begin{array}{l}\text { natural logarithm of } \\
\text { total sales }\end{array}$ \\
\hline Audit Opinion (X2) & $\begin{array}{l}\text { An audit opinion is a opinion statement } \\
\text { or the auditor's opinion on a company's } \\
\text { financial statements, after the auditor } \\
\text { has examined for the reasonableness of } \\
\text { a company's financial statements [8]. }\end{array}$ & $\begin{array}{l}\text { Unqualified opinion } \\
\text { (1) Other Opinion (0) }\end{array}$ \\
\hline $\begin{array}{l}\text { Auditor's Reputation } \\
\text { (Z) }\end{array}$ & $\begin{array}{l}\text { Auditor's reputation is a view on the } \\
\text { good name, achievements, and public } \\
\text { trust of the auditor and KAP where the } \\
\text { auditor works [17]. }\end{array}$ & $\begin{array}{l}\text { Big Four KAP (1) } \\
\text { Non-Big Four KAP } \\
(0)\end{array}$ \\
\hline
\end{tabular}

Source: Various sources, 2020.

Analysis of the data used in this study is to use descriptive statistical analysis and logistic regression analysis. Descriptive statistical analysis to describe a data that is seen from the mean (standard), standard deviation, variance, maximum, minimum, sum, range, kurtosis, and skewness [18]. While logistic regression is use to analyze the independent variables to determine the effect directly on the dependent variable. Logistic regression analysis used to test the hypothesis of the dependent variable consisting of two values representing the occurrence or absence of an event which is usually given the number 0 or number 1 . Data is processed using IBM SPSS Statistics 21 software.

\section{Results and Discussion}

\subsection{Research Result}

\subsubsection{Descriptive Analysis}

From this analysis, it is explained that from a total of 125 units of samples, there are 10 units that do auditor switching while the remaining 115 units do not. The minimum value of the company size is 23 which is the logarithm of total sales from PT Bara Jaya International Tbk (ATPK) in 2016, whereas the maximum value of 32 (natural logarithm of total sales) is owned by Adaro Energy Tbk (ADRO) in 2018. There are 79 units getting a fair opinion without exception, while the remaining 46 units get an opinion other than fair without exception (qualified opinion). A total of 63 units of analysis or 50.4\% of the total that use Big Four Public 
Accounting Firms, the remaining 62 units of analysis or $49.6 \%$ use non big four Public Accounting Firms.

\subsubsection{Inferential Analysis}

The results of the overall model test prove a decrease in -2LL of 22,159 by comparing the initial Log Likelihood value (block number $=0$ ) of 69,692 and the final Log Likelihood value (block number $=1$ ) of 47,533 . Decreased likelihood $(-2 L L)$ shows a better regression model or in other words the model is hypothesized fit with the data [18]. Goodness of fit tests are shown in the Hosmer and Lemeshow Test table. The results of this test show a chi-square value of 1.743 with a significance value of 0.942 . Significance value is greater than 0.05 which means that there is no difference between the model and the data so that the regression model is feasible to be used in further analysis.

Nagelkerke R Square value shows a result of 0.380 which means that the variability of the dependent variable that can be explained by the independent variable is $38 \%$, while the remaining $62 \%$ is explained by other variables outside this research model. The accuracy test of this model is used to assess how much the model accuracy, which in this study, the accuracy percentage of the model in classifying its observations is equal to $91.2 \%$.

Based on the logistic regression test at the 0.05 significance level, the logistic regression model is obtained as follows:

SWITCH $=-2,037-2,144$ ZUP-0,967 ZOA + 1,815 ZRA-4,620 ZUP_ZRA + 0,982 ZOA_ZRA + e.

Table 4. Summary of Hypothesis Testing Results

\begin{tabular}{lccc}
\hline \multicolumn{1}{c}{ Hypothesis } & B & Sig. & Explanation \\
\hline $\begin{array}{l}\mathrm{H}_{1} \text { : Firm size has a negative effect on auditor } \\
\text { switching }\end{array}$ & $-2,144$ & 0,190 & Rejected \\
$\begin{array}{l}\mathrm{H}_{2} \text { : Audit opinion has a negative effect on auditor } \\
\text { switching }\end{array}$ & $-0,967$ & 0,019 & Accepted \\
$\begin{array}{l}\mathrm{H}_{3} \text { : The auditor's reputation strengthens the effect } \\
\text { of company size on auditor switching }\end{array}$ & $-4,620$ & 0,021 & Accepted \\
$\begin{array}{l}\mathrm{H}_{4} \text { : The auditor's reputation strengthens the effect } \\
\text { of audit opinion on auditor switching }\end{array}$ & 0,982 & 0,043 & Rejected \\
\hline
\end{tabular}

Source: Secondary data processed in 2020.

\subsection{Discussion}

\subsubsection{Company Size has No Impact on Auditor Switching}

The results of this study are in line with research conducted by Fakhri, Majidah \& Nurbaiti [4], Winata \& Anisykurlillah [5] and Fauziyyah, Sondakh \& Suwetja [6], stating that company size does not affect the change of auditors in the company. This study failed to find any influence between the size of the company and the occurrence of auditor switching, allegedly because in reality the size of the company seen through its total sales tends not to change auditors by reason of avoiding agency costs and maintaining audit quality. The statement is in line with the sample of the company used that at PT Adaro Energy Tbk (ADRO) which has the largest size of the company with an average total sales during 2015-2018 valued at Rp 41,877,382,834,750.00, does not change auditors for four years namely by continuing to engage with KAP Tanudiredja, Wibisana, Rintis and Partners. In addition, PT Mitra Investindo Tbk (MITI), which has a 
relatively small size of the company with an average total sales during 2015-2018 of Rp $29,717,656,618.00$, also does not change its auditor for four years.

\subsubsection{Audit Opinion has a Negative Effect on Auditor Switching}

The results of this study are consistent with research conducted by Fauziyyah, Sondakh \& Suwetja [6], Faradila \& Yahya [7] and Putra \& Suryanawa [8], showing the influence of audit opinion on the occurrence of auditor changes in a company. So, this research succeeded in proving that if the company had obtained an unqualified opinion on the results of its financial statement audit, then the management would tend to retain its auditors.

\subsubsection{The Auditor's Reputation Strengthens the Effect of Company Size on Auditor Switching}

This research successfully proves that the auditor's reputation can strengthen the influence of company size on the occurrence of auditor switching. So it can be concluded that the greater the size of the company assessed from total sales supported by a good auditor reputation with the Big Four KAP proxy, it will minimize the change of auditors made by the company management. The larger the company with the the business complexity that requires a lot of experienced and capable auditors knowing the client industry specialist well, the more they tend to retain auditors who have had a long-standing engagement with clients, and are supported by reputable auditors who are believed to have good competence and are able to learn the client's industry specialization well too.

\subsubsection{The Auditor's Reputation Unable to Strengthen the Effect of Audit Opinion on Auditor Switching}

The results of this study did not succeed to prove the influence of the auditor's reputation as a moderating variable that was considered able to strengthen the influence of audit opinion on auditor switching on mining companies listed on IDX in 2015-2018. This is thought to be caused by the management who always tried to do the best for the company, so that even if the opinion given is in accordance with what is desired, that is, an unqualified opinion, but if the opinion given is not from a reputable KAP, the management is still trying to replace with a reputable KAP or in this study is proxied by a KAP affiliated with The Big Four KAP.

The results show that the auditor's reputation weakens the audit opinion of the auditor switching in accordance with the sample used in this study, namely PT Baramulti Suksessarana Tbk in 2015, PT Delta Dunia Makmur Tbk in 2015, PT Ratu Prabu Energi Tbk in 2016, PT Golden Eagle Energy Tbk in 2017, and PT Radiant Utama Interinsco Tbk in 2018 which showed that the unqualified opinion given by the Non Big Four KAP caused the management to change the KAP. Thus, an unqualified audit opinion will make management tend to maintain its KAP, but if the KAP used is not affiliated with the Big Four KAP, it will weaken the company's management's decision to maintain its KAP, so that management still tends to try to replace its KAP.

\section{Conclusion}

Based on the results and discussion of the company size effect, the audit opinion on auditor switching is moderated by the auditor's reputation in companies listed on the Indonesia Stock 
Exchange (BEI) in 2015-2018. The size of the company with a logarithm of total sales has no effect on auditor switching allegedly because large companies or small companies tend not to replace their auditors to avoid agency cost.

Audit opinion has a negative effect on auditor switching because a company that has received a fair opinion without exception will cause the management to feel satisfied so that it tends to retain its auditor.

Auditor's reputation strengthens the influence of company size on auditor switching because large companies that have a lot of business complexity require experienced auditors and long-standing engagement with clients, and auditors who are in good standing are considered able to learn the client's industry specialization well and have a lot of experience.

The auditor's reputation is not able to strengthen the influence of audit opinion on auditor switching but instead weakens the influence of audit opinion on auditor switching allegedly because although the opinion given is reasonable without exception, if given by a non-big four $\mathrm{KAP}$, the management tends to still want to replace its KAP so that the audit results more quality and able to be trusted by the public.

\section{References}

[1] T. A. Hartono and A. Rohman, "Analisis Hubungan Auditor-Klien: Faktor-Faktor Yang Mempengaruhi Auditor Switching Di Indonesia," Diponegoro J. Account., vol. 4, no. 4, pp. 1$12,2015$.

[2] A. K. Gharibi and M. S. Geraeely, "Investigating the effective factors on changing auditor: evidences of Iranian firms ,"” Probl. Perspect. Manag., vol. 14, no. 3, pp. 401-406, 2016.

[3] Saidin, R. Arifati, and R. Andini, "Analysis of Effect of Audit Opinion, Kap Size, Financial Trouble, Turn Management, Company Size and Growth Company Auditor Switching on Mining Companies Listed in Indonesia Stock Exchange Period 2011-2014,” J. Account., vol. 2, no. 2, 2016.

[4] M. Fakhri, Majidah, and A. Nurbaiti, "Pengaruh Opini Audit, Ukuran Kantor Akuntan Publik (Kap), Dan Ukuran Perusahaan Terhadap Auditor Switching (Studi Pada Perusahaan Sektor Pertambangan Yang Terdaftar Di Bursa Efek Indonesia Periode 2012-2016)," e-Proceeding Manag., vol. 5, no. 1, pp. 747-752, 2018.

[5] A. S. Winata and I. Anisykurlillah, "Analysis of Factors Affecting Manufacturing Companies in Indonesia Performing a Switching Auditor," vol. 9, no. 1, pp. 82-91, 2017.

[6] W. Fauziyyah, J. J. Sondakh, and I. G. Suwetja, "Pengaruh Financial Distress, Ukuran Perusahaan, Opini Audit, dan Reputasi Kap Terhadap Auditor Switching Secara Voluntary Pada Perusahaan Manufaktur Yang Terdaftar Di Bursa Efek Indonesia," J. EMBA, vol. 7, no. 3, pp. 3628-3637, 2019.

[7] Y. Faradila and M. R. Yahya, "Pengaruh Opini Audit, Financial Distress, dan Pertumbuhan Perusahaan Klien Terhadap Auditor Switching ( Studi Pada Perusahaan Manufaktur Yang Terdaftar Di Bursa Efek Indonesia Tahun 2010-2014 ),” J. Ilm. Mhs. Ekon. Akunt. (JIMEKA, vol. 1, no. 1, pp. 81-100, 2016.

[8] I. G. B. B. P. Putra and I. K. Suryanawa, "Pengaruh Opini Audit Dan Reputasi Kap Pada Auditor Switching Dengan Financial Distress Sebagai Variabel Moderasi," E-Jurnal Akunt. Univ. Udayana, vol. 14, no. 2, pp. 1120-1149, 2016.

[9] N. M. P. Pawitri and K. Yadnyana, "Pengaruh Audit Delay, Opini Audit, Reputasi Auditor dan Pergantian Manajemen pada Voluntary Auditor Switching," E-jurnal Akunt. Univ. Udayana, vol. 10, no. 1, pp. 214-228, 2015.

[10] M. C. Jensen and W. H. Meckling, "Theory of The Firm: Managerial Behavior, Agency Costs and Ownership Structure," J. financ. econ., vol. 3, pp. 305-360, 1976.

[11] M. Spence, “Job Market Signaling,” Q. J. Econ., vol. 87, no. 3, pp. 355-374, 2007.

[12] U. Hilmi and S. Ali, "Analisis Faktor-faktor yang Mempengaruhi Ketepatan Waktu Penyampaian 
Laporan Keuangan (Studi Empiris pada Perusahaan-perusahaan yang Terdaftar di BEJ)," Simp. Nas. Akunt. XI Ikat. Akuntan Indones., 2008.

[13] N. A. Fitriani and Zulaikha, "Analisis Faktor-Faktor Yang Mempengaruhi Voluntary Auditor Switching Di Perusahaan Manufaktur Indonesia,” Diponegoro J. Account., vol. 3, no. 2, pp. 113, 2014.

[14] M. D. Praptitorini and I. Januarti, "Analisis pengaruh kualitas audit, debt default dan opinion shopping terhadap penerimaan opini going concern," J. Akunt. dan Keuang. Indones., vol. 8, no. 1, pp. 78-93, 2011.

[15] N. W. A. Juliantari and N. K. Rasmini, "Auditor Switching Dan Faktor-Faktor Yang Mempengaruhinya," E-Jurnal Akunt. Univ. Udayana, vol. 3, pp. 231-246, 2013.

[16] N. K. S. Udayani and I. D. N. Badera, "Kualitas Audit Sebagai Pemoderasi Pengaruh Pergantian Manajemen Dan Audit Fee Pada Auditor Switching," E-Jurnal Akunt. Univ. Udayana, vol. 20, no. 3, pp. 1820-1847, 2017.

[17] F. O. Hidayanti and Sukirman, "Reputasi Auditor, Ukuran Perusahaan dan Opini Audit Tahun Sebelumnya Dalam Memprediksi Pemberian Opini Audit Going Concern," Account. Anal. J., vol. 3, no. 4, pp. 420-428, 2014.

[18] G. Imam, "Aplikasi Analisis Multivariate dengan Program IBM SPSS 21 Update PLS Regresi," Semarang. Badan Penerbit Univ. Diponegoro. ISBN, vol. 979, no. 015.1, 2013. 